\title{
COST OF ILLNESS IN BENIGN PROSTATIC HYPERPLASIA: A REVIEW
}

\author{
ÁGNES KOVÁCS ${ }^{1,2}$ \\ ${ }^{I}$ PhD student, Department of Health Economics, Corvinus University of Budapest \\ E-mail:dragnes.kovacs@yahoo.com \\ ${ }^{2}$ Employee, Astellas Pharma Hungary, Csörsz u. 49-51. H-1124 Budapest, Hungary
}

The paper provides a systematic review on the cost-of-illness studies in an age-associated condition with high prevalence, benign prostatic hyperplasia (BPH), published in Medline between 2005 and 2015. Overall 11 studies were included, which were conducted in 8 countries. In the US, the annual direct medical costs per patient ranged from $\$ 255$ to $\$ 5,729$, while in Europe from $€ 253$ to $€ 1,251$. In 2008 , in the UK total annual direct medical costs of BPH were $£ 180.8$ million at national level. In the US, overall costs of BPH management in the private sector were estimated at \$3.9 billion annually, of which $\$ 500$ million was attributable to productivity loss (year 1999). Due to demographic factors and possible surgical innovations in the field of urology, the costs of BPH are likely to increase in the future. Over the next decade the age of retirement is projected to rise, consequently, the indirect costs related to agingassociated conditions such as BPH are expected to soar. To promote the transparent and cost-effective management of $\mathrm{BPH}$, development of rational clinical guidelines would be essential that may lead to significant improvement in quality of care as well as reduction in healthcare expenditure.

Keywords: aging, healthcare costs, cost-of-illness, benign prostatic hy perplasia

JEL code: I19 


\section{Introduction}

Benign prostatic hyperplasia (BPH) manifesting in lower urinary tract symptoms (LUTS) is one of the most common urological conditions with a prevalence of $10-46 \%$ in patients over 40 (Speakman et al. 2014). Ageing - the main risk factor for developing BPH - is a major public policy concern, particularly in the fields of social security, pension-systems, and financing and provision of healthcare services (Shrestha 2000). By 2050, there will be 58 million people over 65 living in the European Union (European Commission 2008). Healthcare expenditure in the EU-27 is projected to increase from $7.1 \%$ to $8.4 \%$ of GDP from 2010 to 2060 purely attributable to the effect of an ageing population on healthcare spending (European Commission 2012).

Ageing-associated diseases, such as BPH, type 2 diabetes, dementia, osteoporosis, arthritis, pemphigus, bladder cancer and prostate cancer, have become major cost drivers of healthcare financing (Brodszky et al. 2009, Ersek et al. 2010, Hever et al. 2014, Pentek et al. 2008, Rencz et al. 2014a, Rencz et al. 2014b, Rencz et al. 2015b, Tamas et al. 2014). Given the increasing longevity, the demographic ageing observed in the developed countries and the high prevalence of $\mathrm{BPH}$, more and more men use health care services due to the symptoms of BPH (Boncz et al. 2014, Rencz 2012). Financing the rising demand for healthcare is a great challenge for societies and economies, particularly in times of recession when countries struggle to comply with austerity measures. The treatment of BPH typically depends on the severity of the disease and may involve watchful waiting, pharmacotherapy and a number of surgical procedures. However, costs of these can vary dramatically (Taub et al. 2006); therefore, the economic evaluations of these treatment modalities are very useful to promote cost-effectiveness in healthcare decision-making and facilitate the elimination of the existing inefficiencies from the system. In countries with well-established health technology assessment agencies, economic evaluations are key elements of healthcare decision-making (Gulacsi et al. 2014a, Gulacsi et al. 2014b, Gulacsi et al. 2014c). As the number of patients and as a consequence, costs are continuously increasing, a review of the literature is an appropriate starting point to explore and understand the economic burden imposed by BPH.

Therefore, the objective of the current study is to provide a literature review of cost-of-illness studies in BPH conducted in the past 10 years, and to explore inter-country differences and main cost drivers. 


\section{Methods}

A systematic literature search was performed in the most extensive medical literature database, namely Medline via PubMed. The search strategy consisted of free-text terms and medical subject headings related to the disease or the cost analysis. ${ }^{1}$ The key words for the search were the following: healthcare costs, cost-of-illness, benign prostatic hyperplasia. The search was limited to studies published in English between $1^{\text {st }}$ January, 2005 and $25^{\text {th }}$ March, 2015. Inclusion criteria to the study were: (i) original paper (excluding review or letter), (ii) reports of cost-of-illness studies in BPH (excluding studies where BPH was examined as a comorbidity of another condition). Studies evaluating only a few selected types of treatment, e.g. limited to surgical treatments or selected medications only, were excluded. The papers were selected by two independent reviewer. Study design, year of publication, geographical location, perspective of cost analysis, patient numbers, cost categories assessed, year of costing and cost results were retrieved from all included studies.

\section{Results}

\subsection{Characteristics of the papers}

Literature search yielded overall 159 hits, of which 148 were excluded for the following reasons: 84 studies were not involving BPH or did not report costs, 12 papers were not original articles, 16 studies were other types of economic evaluations (e.g. cost-effectiveness analysis, cost-minimisation analysis) and 36 studies evaluated only a few treatment types or did not report per patient costs, but only costs of the total cohort or the total patient population in a country. Eventually, 11 papers meeting the inclusion and exclusion criteria were included in the current review (Table 1).

\footnotetext{
${ }^{1}$ Medline search strategy: ((bph[Title/Abstract]) OR prostatic hyperplasia[MeSH Terms] OR prostatic hyperplasia[Title/Abstract])) AND ((((costs or cost analysis[MeSH Terms] OR health expenditures[MeSH Terms]) OR health care costs[MeSH Terms]) OR cost of illness[MeSH Terms]) OR cost[Title/Abstract] OR economic burden[Title/Abstract]) NOT review[publication type]
} 
Table 1. Per patient costs of BPH

\begin{tabular}{|c|c|c|c|c|c|c|c|c|c|}
\hline Author (year) & Study design & $\begin{array}{l}\text { Study } \\
\text { year }\end{array}$ & Countries & $\begin{array}{l}\text { Patients } \\
\text { (N) }\end{array}$ & Perspective & $\begin{array}{c}\text { Costs categories } \\
\text { assessed }\end{array}$ & $\begin{array}{l}\text { Year of } \\
\text { costs }\end{array}$ & Time horizon & Results \\
\hline \multirow{6}{*}{ van Exel, 2006} & \multirow{6}{*}{$\begin{array}{c}\text { cross-sectional } \\
\text { questionnaire survey }\end{array}$} & \multirow{6}{*}{$\begin{array}{l}\text { Feb. } \\
2000- \\
\text { May } \\
2003\end{array}$} & France & 991 & \multirow{6}{*}{$\begin{array}{c}\text { payers' } \\
\text { perspective }\end{array}$} & \multirow{6}{*}{$\begin{array}{c}\text { per patient direct } \\
\text { medical costs incl. } \\
\text { diagnostics, treatments } \\
\text { and costs of } \\
\text { complications }\end{array}$} & \multirow{6}{*}{$€, 2003$} & \multirow{6}{*}{1 year } & $€ 639$ \\
\hline & & & Germany & 443 & & & & & $€ 513$ \\
\hline & & & Italy & 671 & & & & & $€ 633$ \\
\hline & & & Poland & 1,823 & & & & & $€ 1,183$ \\
\hline & & & Spain & 952 & & & & & $€ 595$ \\
\hline & & & UK & 177 & & & & & $€ 292$ \\
\hline Cozar, 2013 & $\begin{array}{c}\text { cross-sectional } \\
\text { telephone interviews } \\
\text { (with } 153 \text { GPs and } \\
154 \text { urologists) }\end{array}$ & $\begin{array}{l}\text { April, } \\
\text { May } \\
2010\end{array}$ & Spain & NR & $\begin{array}{c}\text { payers' } \\
\text { perspective }\end{array}$ & $\begin{array}{c}\text { per patient direct } \\
\text { medical costs incl. } \\
\text { diagnostics, treatments }\end{array}$ & $€, 2012$ & 1 year & $€ 253-1,251$ \\
\hline \multirow{2}{*}{ Johansen, 2007} & \multirow{2}{*}{ Markov model } & \multirow{2}{*}{2006} & \multirow{2}{*}{ Norway } & \multirow{2}{*}{1,000} & \multirow{2}{*}{$\begin{array}{l}\text { payers' and } \\
\text { societal } \\
\text { perspectives }\end{array}$} & \multirow{2}{*}{$\begin{array}{l}\text { total costs incl. direct } \\
\text { and indirect costs } \\
\text { (productivity loss and } \\
\text { leisure time loss) }\end{array}$} & \multirow{2}{*}{$€, 2006$} & 4 years & $\begin{array}{c}\text { Payers' perspective } \\
\text { Medication: } € 1,703- \\
2,054 \\
\text { TURP: } € 5,655 \\
\text { Societal perspective } \\
\text { Medication: } € 1,938- \\
2,555 \\
\text { TURP: } € 7,638 \\
\end{array}$ \\
\hline & & & & & & & & 15.5 years & $\begin{array}{c}\text { Payers' perspective } \\
\text { Medication: } € 3,924- \\
4,946 \\
\text { TURP: } € 6,164 \\
\text { Societal perspective } \\
\text { Medication: } € 4,315- \\
\text { 5,861 } \\
\text { TURP: } € 8,307\end{array}$ \\
\hline Bellinger, 2012 & $\begin{array}{l}\text { insurance claim } \\
\text { database analysis }\end{array}$ & $\begin{array}{l}2000- \\
2007\end{array}$ & US & 40,253 & $\begin{array}{c}\text { payers' } \\
\text { perspective }\end{array}$ & $\begin{array}{c}\text { per patient direct } \\
\text { medical costs incl. } \\
\text { diagnostics, treatments }\end{array}$ & \$, 2007 & $\begin{array}{l}1 \text { year (first } \\
\text { year after } \\
\text { diagnosis) }\end{array}$ & $\begin{array}{l}\text { 2000: } \$ 255 \\
\text { 2007: } \$ 344\end{array}$ \\
\hline Saigal, 2005 & $\begin{array}{c}\text { insurance claim } \\
\text { database analysis }\end{array}$ & 1999 & US & 2,013 & $\begin{array}{c}\text { payers' } \\
\text { perspective }\end{array}$ & $\begin{array}{l}\text { per patient direct } \\
\text { medical costs }\end{array}$ & $\$, 1999$ & 1 year & $\begin{array}{l}\text { without medical } \\
\text { claim } \$ 4,193\end{array}$ \\
\hline
\end{tabular}




\begin{tabular}{|c|c|c|c|c|c|c|c|c|c|}
\hline & & & & & & & & & $\begin{array}{c}\text { with medical claim: } \\
\$ 5,729\end{array}$ \\
\hline Saigal, 2007 & $\begin{array}{l}\text { insurance claim } \\
\text { database analysis }\end{array}$ & $\begin{array}{l}1997- \\
2002\end{array}$ & US & 1,952 & $\begin{array}{c}\text { payers' } \\
\text { perspective }\end{array}$ & $\begin{array}{l}\text { per patient direct } \\
\text { medical costs }\end{array}$ & $\$, 2002$ & 5 years & $\begin{array}{c}\text { Medication first } \\
\text { cohort: } \$ 2,193 \\
\text { Surgery first cohort } \\
\$ 12,699\end{array}$ \\
\hline Strope, 2011 & $\begin{array}{c}\text { insurance claim } \\
\text { database analysis }\end{array}$ & $\begin{array}{l}1999- \\
2007 \\
\end{array}$ & US & NR & $\begin{array}{c}\text { payers' } \\
\text { perspective }\end{array}$ & $\begin{array}{l}\text { per patient direct } \\
\text { medical costs }\end{array}$ & $\$, 2007$ & 1 month & $\begin{array}{c}\$ 35-527 \text { (median } \\
\$ 92) \\
\end{array}$ \\
\hline $\begin{array}{c}\text { Disantostefano, } \\
2006\end{array}$ & Markov model & 2004 & US & 1,000 & $\begin{array}{c}\text { societal } \\
\text { perspective }\end{array}$ & $\begin{array}{l}\text { per patient treatment } \\
\text { costs }\end{array}$ & $\$, 2004$ & 20 years & $\begin{array}{c}1^{\text {st }} \text { year: } \\
\text { WW \$195; AB } \\
\text { \$628; } \\
\text { 5-ARI \$900; } \\
\text { Combined therapy } \\
\text { \$1,333; TUMT } \\
\text { \$4,073; TURP } \\
\text { \$7,201 } \\
\text { SSQ years: } \\
\text { WW \$108; AB: } \\
\text { \$541; } \\
\text { 5-ARI \$870; } \\
\text { Combined therapy } \\
\text { \$1,247; TUMT \$54; } \\
\text { TURP \$54 }\end{array}$ \\
\hline
\end{tabular}

5-ARI $=5$-alpha-reductase inhibitor, $\mathrm{AB}=$ alpha-blocker, GP $=$ general practitioner, $\mathrm{NR}=$ not reported, SSQ $=$ subsequent, TUMT $=$ Transurethral microwave therapy, TURP $=$ Transurethral prostatectomy, $\mathrm{WW}=$ watchful waiting 
Four studies were conducted in European countries and seven in the US. There was a multinational research involving six European countries (France, Germany, Italy, Poland, Spain, and the UK). There were 2 cross-sectional studies, 2 Markov model simulations and 7 retrospective analyses of insurance claim databases, respectively. The methodologies used in the cross-sectional surveys were telephone interview and questionnaire survey, respectively. Sample sizes varied from 1,000 to 40,253 but two studies did not report the number of patients enrolled. For the cost calculation, nine studies applied payer's perspective, one societal perspective and one both, respectively. The time horizon of the studies ranged between 1 month and 20 years (average expected lifetime for a BPH patient at the time of diagnosis) while the most commonly used time horizon was 1 year. Year of costs in the studies varied from 1998 to 2012.

\subsection{Costs}

Per patient costs were reported in 8 studies (Table 1), whereas nationwide costs, or costs of a larger cohort in 5 studies (Table 2). As for cost categories, 10 studies considered only direct medical costs and one both direct and indirect costs, respectively. In the study by Disantostefano et al. solely the costs of therapy were estimated. Apart from the direct costs, Johansen et al. included the loss of productivity as well as of leisure time in the indirect costs.

The direct medical costs of BPH varied widely across studies. In the US, the annual direct medical costs per patient ranged between \$255-5,729, while in Europe between €253-1,251. In Norway, costs were estimated at $€ 1,703-7,638$ and $€ 3,924-8,307$ in four- and 15.5-year horizons, respectively, depending on the treatment modalities and the perspective of the cost calculation. In the US, the 5-year direct medical costs were ranging from $\$ 2,193$ to $\$ 12,699$. Both in the US and Europe, mean costs associated with surgically treated patients exceeded those receiving pharmacological treatment. In the US, costs of patients with medical claim $(\$ 5,729)$ were found higher compared to those without it $(\$ 4,193)$. 
Table 2 Costs of larger patient cohorts or total costs at the national level

\begin{tabular}{|c|c|c|c|c|c|c|c|c|c|}
\hline Author (year) & Study design & Study year & Countries & Patients & Perspective & $\begin{array}{c}\text { Costs } \\
\text { categories } \\
\text { assessed }\end{array}$ & $\begin{array}{c}\text { Year of } \\
\text { costs }\end{array}$ & Time frame & Results \\
\hline Litwin, 2005 & $\begin{array}{c}\text { insurance } \\
\text { claim database } \\
\text { analysis }\end{array}$ & $1998-2000$ & US & nationwide & $\begin{array}{c}\text { payers' } \\
\text { perspective }\end{array}$ & $\begin{array}{l}\text { direct medical } \\
\text { costs }\end{array}$ & \$, 1998 & 1 year & \$ 776 million \\
\hline Saigal, 2005 & $\begin{array}{c}\text { insurance } \\
\text { claim database } \\
\text { analysis } \\
\end{array}$ & 1999 & US & $\begin{array}{l}\text { all privately } \\
\text { insured patients }\end{array}$ & $\begin{array}{c}\text { payers' } \\
\text { perspective }\end{array}$ & $\begin{array}{c}\text { direct and } \\
\text { indirect costs }\end{array}$ & \$, 1999 & 1 year & $\$ 3.9$ billion \\
\hline Wei, 2005 & $\begin{array}{c}\text { insurance } \\
\text { claim database } \\
\text { analysis }\end{array}$ & $1990-2000$ & US & nationwide & $\begin{array}{c}\text { payers' } \\
\text { perspective }\end{array}$ & $\begin{array}{l}\text { direct medical } \\
\text { costs excl. } \\
\text { outpatient drug } \\
\text { costs }\end{array}$ & $\$, 2000$ & 1 year & $\$ 1.1$ billion \\
\hline Kirby, 2010 & $\begin{array}{l}\text { Hospital } \\
\text { Episode } \\
\text { Statistics } \\
\text { (HES) }\end{array}$ & $2007-2008$ & UK & nationwide & $\begin{array}{c}\text { payers' } \\
\text { perspective }\end{array}$ & $\begin{array}{l}\text { direct medical } \\
\text { costs }\end{array}$ & $£, 2008$ & 1 year & $\begin{array}{l}£ 180.8 \\
\text { million }\end{array}$ \\
\hline Bellinger, 2012 & $\begin{array}{c}\text { insurance } \\
\text { claim database } \\
\text { analysis }\end{array}$ & $2000-2007$ & US & $\begin{array}{l}\text { Medicare } 5 \% \\
\text { cohort }\end{array}$ & $\begin{array}{c}\text { payers' } \\
\text { perspective }\end{array}$ & $\begin{array}{l}\text { direct medical } \\
\text { costs }\end{array}$ & \$, 2007 & $\begin{array}{l}1 \text { year (first } \\
\text { year after } \\
\text { diagnosis) }\end{array}$ & $\$ 32.3$ million \\
\hline
\end{tabular}


The Triumph project (Trans European Research into the use of Management Policies for LUTS suggestive of BPH) was a one-year prospective, cross-sectional, observational survey including 5,077 patients with LUTS suggestive of BPH from France, Germany, Italy, Poland, Spain and the UK (van Exel et al. 2006). Only direct medical costs were evaluated and data on possible complications such as acute urinary retention, bleeding, renal dysfunction, urinary tract infections, and bladder stones were collected as well. Although patients enrolled in the six countries were quite similar, treatment strategies differed by country. For instance, the average number of annual visits to the urologist ranged from 1.0 (France, Italy, UK) to 2.7 (Germany), transabdominal ultrasonographies from 11\% (UK) to $83 \%$ (Poland), transrectal ultrasonographies from $1 \%$ (UK) to $26 \%$ (France), Prostate Specific Antigen tests from $41 \%$ (Germany) to $88 \%$ (Spain), and free-flow studies from $4 \%$ (Italy) to $26 \%$ (Spain), respectively. The proportion of watchful waiting (WW) (i.e. regular follow-up without applying any specific treatment) was the lowest in Italy and Poland (20\%), whereas the highest in the UK (69\%). Rate of patients on alpha-blockers and phytotherapy ranged from $2 \%$ (the UK) to $9 \%$ (Germany and France), and from $1.4 \%$ (Poland) to $16.5 \%$ (France), respectively. The lowest surgery rate was found in the UK (1.7\%) and the highest in Poland (6.4\%). Total direct medical costs of BPH in France, Germany, Italy, Poland, Spain, and the UK were estimated at $€ 639$, €513, €633, €1,337, €595 and €292, respectively (year 2003). Medications were identified as the most important cost drivers, as they accounted for about three quarters of the total treatment costs (range: from $40 \%$ in France to $89 \%$ in Poland). Costs of surgical procedures accounted for $15 \%$ of total costs and the diagnostic tests for approximately $8 \%$, respectively. Higher severity was associated with higher costs both for voiding (mild \$673, moderate $\$ 906$ and severe \$960) and storage symptoms (\$623, \$865 and $\$ 1,043$ ) (van Exel et al. 2006).

Estimations of costs spent on BPH at national level are available from the US and the UK. In 2008 , in the UK, the total annual direct medical costs of BPH at national level were $£ 180.8$ million (Kirby et al. 2010). In the US, based on insurance claim expenditures, nationwide costs of BPH were \$776 million in 1998 (Litwin et al. 2005), and \$1.1 billion in 2000 (Wei et al. 2005), respectively. However, another study from 1999 reported that overall costs (including direct and indirect costs) of BPH management in the private sector were estimated at $\$ 3.9$ billion annually (Saigal - Joyce 2005).

\section{Discussion}


In the present review, evidence from 11 cost-of-illness studies in BPH, published in the past 10 years, were summarized. The 11 studies were conducted in 8 countries covering Europe and the US. The direct medical costs per patient were estimated at $\$ 255-5,729$ yearly in the US, while $€ 253-1,251$ in Europe. Despite the lack of up-to-date national expenditure data in most countries, based on per patient findings, total costs of disease at national level are estimated to be enormous in each country.

Direct medical costs, including costs of physicians' visits, hospital admissions, diagnostic tests and treatments, were responsible for the majority of the total costs. However, only a small proportion of men with BPH were reported to seek medical help (Rosen et al. 2003), suggesting that the direct costs might have been underestimated. Symptomatic BPH patients may develop complications such as acute urinary retention (AUR), especially when left untreated. Risk for men in their 80s to experience AUR within the next 5 years is nearly 1 in 3 (Emberton et al. 1999). Such complications may significantly increase the direct medical costs of BPH. In 2007/2008 in the UK, the annual total costs associated with the major complications of BPH in the secondary care reached as much as $£ 101.2$ million at national level (Kirby et al. 2010).

Most of the studies currently reviewed have concerned the direct medical costs related to BPH; however, considerable indirect costs may incur as well. Saigal and Joyce, based on data of more than 120,000 privately insured working-age males, found that an average employee missed 7.3 hours of work yearly due to BPH (approximately 7.1 hours due to outpatient care and 0.2 hours due to hospital admissions) (Saigal - Joyce 2005). In this study only a minority of the patients was absent from work in the past year (10\%). Average work loss exceeded 9 days yearly in those reporting some absence temporally related to BPH treatment. Indirect costs of privately insured employees were estimated at \$500 million (year 1999). Costs related to presenteeism (i.e. reduced productivity while at work due to $\mathrm{BPH}$ ) have not been assessed by any of the studies. Nevertheless, BPH has a detrimental effect on the quality of life (Fourcade et al. 2012, Schulz et al. 2002) similar to that experienced in epilepsy, chronic migraine, or in case of severe symptoms associated with psoriasis (Heredi et al. 2014, Moradi et al. 2015, Pentek et al. 2013, Rencz et al. 2015a, Rencz et al. 2014c). Urinary symptoms may bother patients while working, resulting in decreased productivity (presenteeism).

As the population is ageing, the retirement age is increasing in the industrialized countries. The average official retirement age in the OECD-34 was 64.65 years in 2012, but in certain 
countries, such as Australia, the US, Norway, Israel and Iceland, it is higher than 65 years (OECD 2012). Furthermore, in many developed countries, the effective retirement age may exceed the official one by even more than five years, e.g. in France, Belgium and Luxemburg. Over the next decade the retirement age is projected to soar, therefore, the indirect costs related to ageing-associated conditions such as BPH are expected to rise as well. In light of the findings of the present review, presenteeism due to BPH seems to be understudied. Future investigations are highly encouraged to explore the share of indirect costs between absenteeism and presenteeism.

The potential limitations of this study involve heterogeneity of the studies in terms of sample sizes, characteristics of the patient populations, study designs, countries, variety of treatments used, differences in unit costs and methods for cost calculation. These make the direct comparisons between these studies difficult. Year of costing in the studies ranged between 1999 and 2012. Since 1999, as the technology has evolved and new medicinal products have become available for the treatment of $\mathrm{BPH}$, cost patterns could have changed. Moreover, this review did not evaluate studies which reported costs for a single or a limited number of selected treatment options.

\section{Conclusion}

In summary, $\mathrm{BPH}$ is an age-associated disease affecting more and more males over the age of 40. Given the demographic ageing, increasing longevity and the high prevalence of the disease, BPH poses a significant economic burden on healthcare budgets in the developed countries. Due to demographic factors and possible surgical innovations in the field of urology, the costs of BPH are likely to increase in the future. The higher number of patients will require more trained urologists to ensure sufficient capacity for the optimized management of BPH. Over the next decade the retirement age is projected to rise, therefore, the indirect costs related to ageing-associated conditions such as BPH are expected to soar. To promote the transparent and cost-effective management of $\mathrm{BPH}$, development of reasonable clinical guidelines would be essential that may lead to significant improvement in quality of care as well as reduction in healthcare expenditure. 


\section{References}

Average effective age of retirement versus the official age in 2012 in OECD countries (2012): http://www.oecd.org/els/emp/Summary_2012_values.xls. Accessed: 07.05.2015.

Bellinger, A.S. - Elliott, S.P. - Yang, L. - Wei, J.T. - Saigal, C.S. - Smith, A. - Wilt, T.J. Strope, S.A. (2012): Changes in initial expenditures for benign prostatic hyperplasia evaluation in the Medicare population: a comparison to overall Medicare inflation. Journal of Urology 187(5): 1739-1746.

Boncz, I. - Vajda, R. - Agoston, I. - Endrei, D. - Sebestyen, A. (2014): Changes in the health status of the population of Central and Eastern European countries between 1990 and 2010. European Journal of Health Economics 15(1): 137-141.

Brodszky, V. - Balint, P. - Geher, P. - Hodinka, L. - Horvath, G. - Koo, E. - Pentek, M. Polgar, A. - Sesztak, M. - Szanto, S. - Ujfalussy, I. - Gulacsi, L. (2009): Disease burden of psoriatic arthritis compared to rheumatoid arthritis, Hungarian experiment. Rheumatology International 30(2): 199-205.

Commission of the European Communities. Regions 2020 - demographic challenges for European regions

(2008):

ec.europa.eu/regional_policy/sources/docoffic/working/regions2020/pdf/regions2020_d

emographic.pdf. Accessed: 07.05.2015.

Cozar, J.M. - Huerta, A. (2013): Care management of patients with benign prostatic hyperplasia in Spain [Manejo asistencial del paciente con hiperplasia benigna de próstata en España]. Actas Urológicas Españolas-English edition37(1): 60-61.

DiSantostefano, R.L. - Biddle, A.K. - Lavelle, J.P. (2006): An evaluation of the economic costs and patient-related consequences of treatments for benign prostatic hyperplasia. BJU International 97(5):1007-1016.

Emberton, M. - Anson, K. (1999): Acute urinary retention in men: an age old problem. British Medical Journal 318(7188): 921-925.

Ersek, K. - Kovacs, T. - Wimo, A. - Karpati, K. - Brodszky, V. - Pentek, M. - Jonsson, L. Gustavsson, A. - McDaid, D. - Kenigsberg, P.A. - Valtonen, H. - Gulacsi, L. (2010): Costs of dementia in Hungary. The Journal of Nutrition Health and Aging 14(8): 633639.

Fourcade, R.O. - Lacoin, F. - Roupret, M. - Slama, A. - Le Fur, C. - Michel, E. - Sitbon, A. - Cotte, F.E. (2012): Outcomes and general health-related quality of life among patients medically treated in general daily practice for lower urinary tract symptoms due to benign prostatic hyperplasia. World Journal of Urology 30(3): 419-426.

Gulacsi, L. - Pentek, M. (2014a): HTA in Central and Eastern European countries; the 2001: a space odyssey and efficiency gain. European Journal of Health Economics 15(7):675680.

Gulacsi, L. - Rencz, F. - Pentek, M. - Brodszky, V. - Lopert, R. - Hever, N.V. - Baji, P. (2014b): Transferability of results of cost utility analyses for biologicals in inflammatory conditions for Central and Eastern European countries. European Journal of Health Economics 15(1): 27-34.

Gulacsi, L. - Rotar, A.M. - Niewada, M. - Loblova, O. - Rencz, F. - Petrova, G. - Boncz, I. - Klazinga, N.S. (2014c): Health technology assessment in Poland, the Czech Republic, Hungary, Romania and Bulgaria. European Journal of Health Economics 15 (1): 13-25. 
Heredi, E. - Rencz, F. - Balogh, O. - Gulacsi, L. - Herszenyi, K. - Hollo, P. - Jokai, H. Karpati, S. - Pentek, M. - Remenyik, E. - Szegedi, A. - Brodszky, V. (2014): Exploring the relationship between EQ-5D, DLQI and PASI, and mapping EQ-5D utilities: a cross-sectional study in psoriasis from Hungary. European Journal of Health Economics 15(1): 111-119.

Hever, N.V. - Pentek, M. - Ballo, A. - Gulacsi, L. - Baji, P. - Brodszky, V. - Damasdi, M. Bognar, Z. - Toth, G. - Buzogany, I. - Szanto, A. (2014): Health Related Quality of Life in Patients with Bladder Cancer: A Cross-Sectional Survey and Validation Study of the Hungarian Version of the Bladder Cancer Index. Pathology and Oncology Research.

Johansen, T.E. - Istad, J.A. (2007): Long-term cost analysis of treatment options for benign prostatic hyperplasia in Norway. Scandinavian journal of urology and nephrology 41(2): 124-131.

Kirby, R.S. - Kirby, M. - Fitzpatrick, J.M. (2010): Benign prostatic hyperplasia: counting the cost of its management. BJU International 105(7): 901-902.

Litwin, M.S. - Saigal, C.S. - Yano, E.M. - Avila, C. - Geschwind, S.A. - Hanley, J.M. Joyce, G.F. - Madison, R. - Pace, J. - Polich, S.M. - Wang, M. (2005): Urologic diseases in America Project: analytical methods and principal findings. Journal of Urology 173(3): 933-937.

Moradi, M. - Rencz, F. - Brodszky, V. - Moradi, A. - Balogh, O. - Gulacsi, L. (2015): Health status and quality of life in patients with psoriasis: an Iranian cross-sectional survey. Archives of Iranian Medicine 18(3): 153-159.

Pentek, M. - Bereczki, D. - Gulacsi, L. - Mikudina, B. - Aranyi, Z. - Juhos, V. - Baji, P. Brodszky, V. (2013): Survey of adults living with epilepsy in Hungary: health-related quality of life and costs [Epilepsziával élö felnőttek felmérése Magyarországon: életminőség és költségek]. Ideggyógyászati Szemle 66(7-8): 251-261.

Pentek, M. - Horvath, C. - Boncz, I. - Falusi, Z. - Toth, E. - Sebestyen, A. - Majer, I. Brodszky, V. - Gulacsi, L. (2008): Epidemiology of osteoporosis related fractures in Hungary from the nationwide health insurance database, 1999-2003. Osteoporos International 19(2): 243-249.

Rencz, F. (2012): Health economics analysis of benign prostatic hyperplasia [A jóindulatú prosztata-megnagyobbodás egészség-gazdaságtani elemzése]. Köz-Gazdaság 7(3): $135-151$.

Rencz, F. - Brodszky, V. - Péntek, M. - Balogh, O. - Remenyik, É. - Szegedi, A. - Holló, P. - Kárpáti, S. - Jókai, H. - Herszényi, K. - Herédi, E. - Szántó, S. - Gulácsi, L. (2014a): Disease burden of psoriasis associated with psoriatic arthritis in Hungary[Arthritis psoriaticával társuló középsúlyos és súlyos psoriasis betegségterhe Magyarországon]. Orvosi Hetilap 155(48): 1913-1921.

Rencz, F. - Brodszky, V. - Pentek, M. - Bereczki, D. - Gulacsi, L. (2015a): Health state utilities for migraine based on attack frequency: a time trade-off study. Neurological Sciences 36(2): 197-202.

Rencz, F. - Brodszky, V. - Varga, P. - Gajdacsi, J. - Nyirady, P. - Gulacsi, L. (2014b): The economic burden of prostate cancer. A systematic literature overview of registry-based studies [A prosztatarák gazdasági terhe nagy betegregiszterek alapján]. Orvosi Hetilap 155(13): 509-520. 
Rencz, F. - Gulacsi, L. - Tamasi, B. - Karpati, S. - Pentek, M. - Baji, P. - Brodszky, V. (2015b): Health related quality of life and its determinants in pemphigus: a systematic review and meta-analysis. British Journal of Dermatology.

Rencz, F. - Hollo, P. - Karpati, S. - Pentek, M. - Remenyik, E. - Szegedi, A. - Balogh, O. Heredi, E. - Herszenyi, K. - Jokai, H. - Brodszky, V. - Gulacsi, L. (2014c): Moderate to severe psoriasis patients' subjective future expectations regarding health-related quality of life and longevity. Journal of the European Academy of Dermatology and Venereology.

Rosen, R. - Altwein, J. - Boyle, P. - Kirby, R.S. - Lukacs, B. - Meuleman, E. - O'Leary, M.P. - Puppo, P. - Robertson, C. - Giuliano, F. (2003): Lower urinary tract symptoms and male sexual dysfunction: the multinational survey of the aging male (MSAM-7). European Urology 44(6): 637-649.

Saigal, C.S. - Joyce, G. (2005): Economic costs of benign prostatic hyperplasia in the private sector. Journal of Urology 173(4): 1309-1313.

Saigal, C.S. - Movassaghi, M. - Pace, J. - Joyce, G. (2007): Economic evaluation of treatment strategies for benign prostatic hyperplasia-is medical therapy more costly in the long run? Journal of Urology 177(4): 1463-1467; discussion 1467.

Schulz, M.W. - Chen, J. - Woo, H.H. - Keech, M. - Watson, M.E. - Davey, P.J. (2002): A comparison of techniques for eliciting patient preferences in patients with benign prostatic hyperplasia. Journal of Urology 168(1):155-159.

Shrestha, L.B. (2000): Population aging in developing countries. Health Affairs (Millwood) 19(3): 204-12.

Speakman, M. - Kirby, R. - Doyle, S. - Ioannou, C. (2014): Burden of male lower urinary tract symptoms (LUTS) suggestive of benign prostatic hyperplasia (BPH) - focus on the UK. BJU International.

Strope, S.A. - Elliott, S.P. - Smith, A. - Wei, J.T. - Wilt, T.J. - Saigal, C.S. (2011): Urologist practice styles in the initial evaluation of elderly men with benign prostatic hyperplasia. Urology 77(3): 535-540.

Tamas, G. - Gulacsi, L. - Bereczki, D. - Baji, P. - Takats, A. - Brodszky, V. - Pentek, M. (2014): Quality of life and costs in Parkinson's disease: a cross sectional study in Hungary. PLoS One 9(9): e107704.

Taub, D.A. - Wei, J.T. (2006): The economics of benign prostatic hyperplasia and lower urinary tract symptoms in the United States. Current Urology Reports 7(4): 272-281.

The 2012 Ageing Report Economic and budgetary projections for the 27 EU Member States (2010-2060).

http://ec.europa.eu/economy_finance/publications/european_economy/2012/pdf/ee2012-2_en.pdf. Accessed: 07.05.2015.

van Exel, N.J. - Koopmanschap, M.A. - McDonnell, J. - Chapple, C.R. - Berges, R. Rutten, F.F. (2006): Medical consumption and costs during a one-year follow-up of patients with LUTS suggestive of BPH in six european countries: report of the TRIUMPH study. European Urology 49(1): 92-102.

Wei, J.T. - Calhoun, E. - Jacobsen, S.J. (2005): Urologic diseases in America project: benign prostatic hyperplasia. Journal of Urology 173(4): 1256-1261. 
